\title{
Retreat sites of rain forest stream frogs are not a reservoir for Batrachochytrium dendrobatidis in northern Queensland, Australia
}

\author{
Jodi J. L. Rowley ${ }^{1, *}$, Lee F. Skerratt ${ }^{2}$, Ross A. Alford ${ }^{1}$, Ruth Campbell ${ }^{2}$ \\ ${ }^{1}$ Amphibian Disease Ecology Group, School of Marine and Tropical Biology, and ${ }^{2}$ Amphibian Disease Ecology Group, \\ School of Veterinary and Biomedical Sciences, James Cook University, Townsville, Queensland 4811, Australia
}

\begin{abstract}
Chytridiomycosis is a potentially fatal disease of amphibians caused by Batrachochytrium dendrobatidis, and is implicated in declines and extinctions of amphibian populations and species around the world. To cause local host extinction, a disease organism must persist at low host densities. One mechanism that could facilitate this is the ability to persist in the environment. In the laboratory, $B$. dendrobatidis spreads by both frog-to-frog and environment-to-frog transmission, and can persist on a number of biotic substrates. In the field, $B$. dendrobatidis has been detected on environmental samples taken during an epidemic, but it is not known if it persists in the environment when endemic. Retreat sites of 2 species of Australian rain forest stream frogs Litoria lesueuri and $L$. nannotis were sampled 0 to $3 \mathrm{~d}$ after occupation during the wet and dry seasons in northern Queensland, Australia, where chytridiomycosis has been endemic for at least $10 \mathrm{yr}$. The intensity and prevalence of infection in frogs during sampling were comparatively low compared with epidemics. Diagnostic quantitative polymerase chain reaction did not detect $B$. dendrobatidis in any retreat site samples. It thus appears that retreat sites are not a major environmental source of infection when B. dendrobatidis occurs at low prevalence and intensity on frogs. This suggests that control efforts may not need to eliminate the organism from the environment, at least when prevalence and intensity of infection are low in frogs. Simply treating hosts may be effective at controlling the disease in the wild.
\end{abstract}

KEY WORDS: Batrachochytrium dendrobatidis - Amphibian chytrid fungus - Chytridiomycosis · Environmental reservoir $\cdot$ Disease transmission $\cdot$ Frogs

\section{INTRODUCTION}

Amphibian species around the world are declining at an alarming rate, many of them to extinction (Blaustein \& Wake 1990, Alford \& Richards 1999, Kiesecker et al. 2001, Stuart et al. 2004). Currently, approximately $43 \%$ of all known amphibian species are considered to be declining (Stuart et al. 2004). Many of these declines are thought to be due to the amphibian disease chytridiomycosis (Berger et al. 1998, Lips et al. 2006), which can be fatal to many species and is implicated in mass mortalities, population declines and extinctions in Australia, New Zealand, Central and North America, Europe and Africa (Berger et al. 1998, Lips 1999, Bosch et al. 2001, Bradley et al. 2002, Muths et al. 2003, Bell et al. 2004, Weldon \& Du Preez 2004, Lips et al. 2005, 2006).

Chytridiomycosis is caused by the pathogen Batrachochytrium dendrobatidis, which belongs to the order Chytridiales (Longcore et al. 1999). Members of this order, commonly referred to as chytrids, are ubiquitous fungi found in aquatic habitats and moist soils (Sparrow 1960). They occur as saprobes or parasites on a wide range of substrates including algae, other aquatic fungi, aquatic and terrestrial plants, spores, microscopic animals and their eggs, and chitinous insect exoskeletons (Sparrow 1960), and subsist by degrading cellulose, chitin and keratin (Powell 1993). A number of chytrids are parasitic, infecting plants, algae, protists, invertebrates and vertebrates (Powell 1993). 
B. dendrobatidis is the only chytrid known to cause disease in vertebrate hosts (Berger et al. 1998), presumably breaking down keratin that occurs in the epidermis of adult amphibians and the mouthparts of larval anurans. Chytridiomycosis can cause rapid mortality (Nichols et al. 2001), with infected frogs of susceptible species dying within 3 wk of infection in the laboratory (Berger et al. 1998, 2004). In the laboratory, the disease is highly contagious (Nichols et al. 2001), spreading within and among individuals via motile, waterborne zoospores (Longcore et al. 1999).

One of the unusual aspects of chytridiomycosis is that it drives many host species to local extinction during outbreaks (Berger et al. 1998, Lips et al. 2006). For a pathogen to cause local host extinction it must be capable of persisting and infecting new hosts even at very low host population densities (Anderson \& May 1986, Dobson \& May 1986). One potential mechanism for this is the persistence and growth of Batrachochytrium dendrobatidis in tadpoles and adults that do not die from infection (Berger et al. 1998, 1999, 2004, Daszak et al. 1999). The broad host range of $B$. dendrobatidis also provides a reservoir of infection, enabling the species most susceptible to chytridiomycosis to be driven to extinction (Berger et al. 2004). An alternative source of infection that could facilitate extinction is the persistence of free-living stages (Daszak \& Cunningham 1999, Godfray et al. 1999).

A number of aquatic pathogens are able to persist as viable organisms in the environment by forming biofilms on both abiotic and biotic surfaces (Carli et al. 1993, Hood \& Winter 1997, Signoretto et al. 2005). Zoospores of many chytrids can persist in films of water on plants and in soil, and in ponds and rivers (Carlile \& Watkinson 1994), and have been detected on mossy rocks (Dewel et al. 1985) and canopy leaves (Longcore 2005). In the laboratory, Batrachochytrium dendrobatidis can be cultured on tryptone agar without keratin or keratin derivatives (Longcore et al. 1999, Pessier et al. 1999), will persist in sterilised water for several weeks and will grow for at least one generation on cleaned epidermal keratin or dead amphibians (Longcore et al. 1999). In addition, zoosporangia can attach to and grow on dead algae and insect exoskeletons (Johnson \& Speare 2003) and survive for at least 3 mo in sterile sand or bird feathers (Johnson \& Speare 2005). Another source of infection that could facilitate extinction is the ability of $B$. dendrobatidis to infect alternative hosts. All these factors indicate that $B$. dendrobatidis may be able to do some or all of the following: persist for some time in the environment, grow saprophytically, or infect alternate hosts (Longcore et al. 1999).

Various modes of transmission have been demonstrated in the laboratory and in mesocosms. Direct transmission is known to occur via contact from frogto-frog (G. Marantelli pers. comm.), while indirect transmission can occur between frogs via substrates in mesocosms (G. Marantelli pers. comm.) and from frog to water to frog or tadpole (Berger et al. 1998, Parris \& Cornelius 2004, Rachowicz \& Vredenburg 2004).

During a recent mass mortality event in Panama, Lips et al. (2006) detected Batrachochytrium dendrobatidis via PCR (polymerase chain reaction) on 6 of 7 substrate samples associated with dead frogs and on 1 of 9 stream boulders. However, it is not known if $B$. dendrobatidis is present on substrates only during epidemics, nor is it known whether $B$. dendrobatidis persists on these substrates or if transmission to amphibians occurs.

If Batrachochytrium dendrobatidis can persist or grow in the environment, this will be an important source of infection, particularly if environmental persistence occurs in sites where frogs spend large proportions of their time, such as retreat sites. Particularly during daylight hours, nocturnal frogs usually remain motionless in species-specific retreat sites. Most species of Australian rain forest stream frog occupy these sites from $12 \mathrm{~h}$ to $5 \mathrm{~d}$ at a time, and can return to them repeatedly (J. J. L. Rowley \& R. A. Alford unpubl. data). Retreat sites, therefore, might provide opportunities for reinfection of individuals and transmission between individuals. This could be particularly important because the highest intensities of infection with $B$. dendrobatidis occur on the ventral surfaces of frogs (Berger et al. 2005), which are most often in contact with substrates. We examined the possibility that reinfection and transmission might occur via contaminated substrates by using diagnostic PCR to determine if $B$. dendrobatidis persisted in the diurnal retreat sites of 2 species of rain forest stream frog known to be infected with $B$. dendrobatidis in the field.

\section{MATERIALS AND METHODS}

The diurnal retreat sites used by most species of frogs are unknown. We located the diurnal retreat sites used by 2 species of frogs (Litoria lesueuri and L. nannotis) by tracking individuals at 3 relatively undisturbed rain forest streams in northern Queensland, Australia; Frenchman Creek, in Wooroonooran National Park $\left(17^{\circ} 20^{\prime} \mathrm{S}, 145^{\circ} 55^{\prime} \mathrm{E}, 20\right.$ to $100 \mathrm{~m}$ above sea level [asl]), and Python Creek (17 $46^{\prime} \mathrm{S}, 145^{\circ} 35^{\prime} \mathrm{E}, 200 \mathrm{~m}$ asl) and an unnamed creek ('Lower Tully Creek', $17^{\circ} 48^{\prime} \mathrm{S}$, $145^{\circ} 41^{\prime} \mathrm{E}, 70 \mathrm{~m}$ asl) in Tully Falls Forest Reserve. Surveys were conducted in both the wet and the dry seasons at each site; each survey was approximately $16 \mathrm{~d}$ in duration. Mean air temperature in the wet season was $25^{\circ} \mathrm{C}$ (range $=21$ to $32^{\circ} \mathrm{C}$ ) and in the dry season was $18^{\circ} \mathrm{C}$ (range $=13$ to $25^{\circ} \mathrm{C}$ ). 
During the study, we tracked large to medium-sized hylid frogs of the 2 species Litoria lesueuri and Litoria nannotis and swabbed their diurnal retreat sites. Recently, the taxonomy of the L. lesueuri group has been revised (Donnellan \& Mahony 2004). Two species, L. jungguy and L. wilcoxii, occur in sympatry in the region, may hybridise, and are indistinguishable on the basis of morphology (Donnellan \& Mahony 2004). We therefore continue to refer to them as L. lesueuri. We tracked L. nannotis at Python Creek from 23 July to 6 August 2004 and 25 March to 8 April 2004, and L. lesueuri at Frenchman Creek from 15 to 29 March and 3 to 17 August 2005 and at Lower Tully Creek from 22 February to 9 March and 25 August to 9 September 2005. Frogs were tracked using either radio telemetry or harmonic radar direction finding (Langkilde \& Alford 2002). Only frogs weighing $>11 \mathrm{~g}$ were tracked via radio telemetry. Radio transmitters (Models BD-2N and BD-2NT; Holohil Systems; weighing approximately $0.67 \mathrm{~g}$, including harness, and with a battery life of approximately $3 \mathrm{wk}$ ) were attached to a harness made of silicone tubing, designed to minimise restrictions on movement and avoid causing discomfort to the frog. Frogs that were too small to be radio tracked, as well as a number of larger individuals, were tracked using harmonic radar tracking. This required attachment of a small diode to the same specially designed harness (weighing approximately $0.27 \mathrm{~g}$, including harness). Frogs were fitted with tracking devices in situ and released at their point of capture in $<5$ min. Tracking devices and harnesses did not weigh $>6 \%$ of the frogs' total body weights, which is just over half the recommended maximum relative weight for an attached tag (10\% of the body weight; Richards et al. 1994). The weights of frogs tracked did not change over the study period (Wilcoxon's signed ranks test; $Z=-1.361$, $\mathrm{p}=$ $0.173, \mathrm{n}=70$ ), and frogs with tracking devices attached appeared to use retreat sites similarly to individuals without tracking devices; tracked frogs were commonly observed in close association with, and sharing retreat sites with, frogs without tracking devices.

Frogs fitted with radio transmitters were tracked using a 3-element folding Yagi antennae (A.F. Antronics) and Habit Research HR2500 Osprey VHF receivers. Frogs fitted with diodes were tracked using a portable RECCO R5 transmitter-receiver unit (Recco Rescue Systems).

After we located a frog in a diurnal retreat site, we flagged the site, photographed its position, and constructed a detailed diagram allowing us to accurately relocate the site. We returned to retreat sites approximately 24, 48 and $72 \mathrm{~h}$ after initial location, and, if the frog had left, we swabbed its exact previous location 5 times with a sterile cotton swab (Medical Wire \& Equipment Co.).
Diurnal retreat sites for Litoria lesueuri were typically on the ground, on leaf litter, gravel, soil, or clay, and it was possible to sample almost every site. In contrast, diurnal retreat sites for L. nannotis were typically inaccessible, being under large boulders, in rock fissures, or in caves. While it was possible to swab individual retreat sites of $L$. lesueuri over time, it was not possible to swab most of the L. nannotis retreat sites found during 2004. We therefore focused on 2 accessible sites under waterfalls at Python Creek, where we always found aggregations of $L$. nannotis during the day, and swabbed these sites during 2005, at intervals of approximately $4 \mathrm{~d}$. Although we attempted to relocate each $L$. lesueuri retreat site every $24 \mathrm{~h}$, there were a number of instances when we were unable to relocate the retreat site of a frog.

Individual Litoria lesueuri were swabbed pre- and post-tracking by swabbing their ventral surface, hands and feet with a sterile cotton swab. These samples and samples taken from retreat sites were evaluated for the presence of Batrachochytrium dendrobatidis using Taqman diagnostic quantitative PCR (Boyle et al. 2004). DNA was extracted with PrepMan Ultra and amplified using the primers ITSI-3 Chytr and 5.8S Chytr (Boyle et al. 2004). Each sample was tested in triplicate, and a sample was only recorded as positive if all 3 replicates indicated the presence of $B$. dendrobatidis. If only 1 or 2 replicates were positive for the presence of $B$. dendrobatidis, the sample was regarded as a 'suspicious positive' and retested. As a large number of samples $(>400)$ were collected from L. lesueuri retreat sites, we only evaluated samples collected from sites used by frogs that tested positive or suspicious positive for B. dendrobatidis.

\section{RESULTS}

Infection prevalence was low for Litoria lesueuri during the survey periods. At Frenchman Creek, infection prevalence was only $4.5 \%(\mathrm{n}=22)$ during the wet season surveys and $7.7 \%(\mathrm{n}=26)$ during the dry season surveys. Similarly, at Lower Tully Creek, infection prevalence was $6.3 \%(\mathrm{n}=16)$ during surveys in the wet season surveys and $17.4 \%(n=23)$ during the dry season surveys. In frogs that tested positive or suspicious positive for Batrachochytrium dendrobatidis, infection intensity was also low (Table 1).

Of the 81 retreat site swabs from 36 Litoria lesueuri retreat sites, Batrachochytrium dendrobatidis was detected using quantitative PCR from only 1 sample (1.2\% of samples tested). Of the 41 swabs taken of L. nannotis retreat sites, $B$. dendrobatidis was detected in 3 samples ( $7.3 \%$ of the retreat sites tested). Because all detected levels of $B$. dendrobatidis were very low, 
Table 1. Presence of Batrachochytrium dendrobatidis at retreat sites 0 to $3 \mathrm{~d}$ after use by Litoria lesueuri that tested positive or suspicious positive for $B$. dendrobatidis. -: no data

\begin{tabular}{|c|c|c|c|c|c|c|c|}
\hline \multirow[t]{2}{*}{ Season } & \multirow[t]{2}{*}{ Site } & \multirow[t]{2}{*}{$\begin{array}{c}\text { Frog ID } \\
\text { no. }\end{array}$} & \multicolumn{2}{|c|}{$\begin{array}{l}\text { Intensity of } B \text {. dendrobatidis infection } \\
\text { (estimated no. of zoospore genomes swab }{ }^{-1} \text { ) }\end{array}$} & \multirow[t]{2}{*}{$\begin{array}{c}\text { Days } \\
\text { since use }\end{array}$} & \multicolumn{2}{|c|}{$\begin{array}{l}\text { Number of retreat } \\
\text { sites testing }\end{array}$} \\
\hline & & & Pre-tracking & Post-tracking & & Negative & Positive \\
\hline \multirow[t]{4}{*}{ Wet } & Frenchman Creek & 1 & $<1^{\mathrm{a}}$ & $<1^{\mathrm{a}}$ & 1 & 1 & 0 \\
\hline & & & & & 3 & 1 & 0 \\
\hline & Lower Tully Creek & 2 & 6 & $4^{\mathrm{a}}$ & 1 & 4 & 0 \\
\hline & & & & & 2 & 3 & 0 \\
\hline \multirow[t]{28}{*}{ Dry } & Frenchman Creek & 3 & 57 & - & 1 & 3 & 0 \\
\hline & & & & & 2 & 2 & 0 \\
\hline & & & & & 3 & 1 & 0 \\
\hline & & & & & $1^{\mathrm{b}}$ & 1 & 0 \\
\hline & & 4 & 2327 & - & 1 & 2 & 0 \\
\hline & & & & & 2 & 2 & 0 \\
\hline & Frenchman Creek & 5 & $<1^{\mathrm{a}}$ & - & 1 & 5 & 0 \\
\hline & Lower Tully Creek & & & & 2 & 4 & 0 \\
\hline & & & & & 3 & 3 & 0 \\
\hline & & 6 & $<1$ & 0 & 0 & 1 & 0 \\
\hline & & & & & 1 & 4 & 0 \\
\hline & & & & & 2 & 4 & 0 \\
\hline & & & & & 3 & 2 & $0^{\mathrm{c}}$ \\
\hline & & & & & $1^{\mathrm{b}}$ & 1 & 0 \\
\hline & & 7 & 0 & 498 & 0 & 0 & 0 \\
\hline & & & & & 1 & 1 & 0 \\
\hline & & & & & 2 & 2 & 0 \\
\hline & & & & & 3 & 2 & 0 \\
\hline & & 8 & $1^{\mathrm{a}}$ & 0 & $0^{\mathrm{b}}$ & 1 & 0 \\
\hline & & & & & 1 & 5 & 0 \\
\hline & & & & & 2 & 5 & 0 \\
\hline & & & & & 3 & 2 & 0 \\
\hline & & 9 & 8 & 41 & 1 & 4 & 0 \\
\hline & & & & & 2 & 4 & 0 \\
\hline & & & & & 3 & 4 & 0 \\
\hline & & 10 & 121 & - & 1 & 1 & 0 \\
\hline & & & & & 2 & 3 & 0 \\
\hline & & & & & 3 & 3 & 0 \\
\hline Total & & & & & & 81 & 0 \\
\hline \multicolumn{8}{|c|}{ 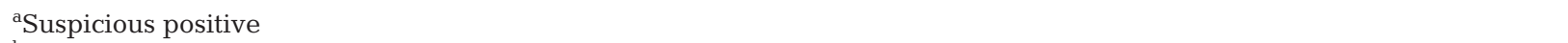 } \\
\hline \multicolumn{8}{|c|}{${ }^{\mathrm{b}}$ Frog present at retreat site for over $48 \mathrm{~h}$} \\
\hline \multicolumn{8}{|c|}{$\begin{array}{l}\text { 'Initially } 1 \text { sample tested positive for } B \text {. dendrobatidis in } 1 \text { of } 3 \text { wells, estimated }<1 \text { zoospore genome equivalent present } \\
\text { retested negative in all } 3 \text { wells }\end{array}$} \\
\hline
\end{tabular}

and no swabs tested positive on all 3 replicate tests, we regarded these only as suspicious positives and retested them. On retesting, all samples were negative for B. dendrobatidis in all 3 wells (Tables $1 \& 2$ ).

\section{DISCUSSION}

The retreat sites we tested did not harbour Batrachochytrium dendrobatidis within 0 to $3 \mathrm{~d}$ after use, as determined by swabbing and diagnostic PCR. It appears that retreat sites are not a reservoir of infection when $B$. dendrobatidis occurs at low prevalence and intensity on frogs. It is also likely that they are not a major mechanism of transmission within populations where $B$. dendrobatidis occurs at low prevalence and intensity, unless transmission occurs shortly after (<12 h) B. dendrobatidis zoospores are shed at a retreat site by an infected frog.

Both the prevalence and intensity of infection were low for Litoria lesueuri when retreat sites were sampled. The prevalence and intensity of infection for L. nannotis at the time of the retreat site survey are unknown; however, in a creek adjacent to Python Creek at similar times of the year, they were $50 \%$ and 35 zoospore genome equivalents per swab, respectively, in the dry season, and $17 \%$ and 5 zoospore genome equivalents per swab in the wet season (K. R. McDonald \& L. F. Skerratt un- 
Bell BD, Carver S, Mitchell NJ, Pledger S (2004) The recent decline of a New Zealand endemic: How and why did populations of Archey's frog Leiopelma archeyi crash over 1996-2001? Biol Conserv 120:189-199

Berger L, Speare R, Daszak P, Green DE and 10 others (1998) Chytridiomycosis causes amphibian mortality associated with population declines in the rainforests of Australia and Central America. Proc Natl Acad Sci USA 95:9031-9036

Berger L, Speare R, Hyatt A (1999) Chytrid fungi and amphibian declines: overview, implications and future directions. In: Campbell A (ed) Declines and disappearances of Australian frogs. Environment Australia, Canberra, p 23-33

Berger L, Speare R, Hines HB, Marantelli G and 10 others (2004) Effect of season and temperature on mortality in amphibians due to chytridiomycosis. Aust Vet J 82:434-439

Berger L, Speare R, Skerratt LF (2005) Distribution of Batrachochytrium dendrobatidis and pathology in the skin of green tree frogs Litoria caerulea with severe chytridiomycosis. Dis Aquat Org 68:65-70

Blaustein AR, Wake DB (1990) Declining amphibian populations: a global phenomenon? Trends Ecol Evol 5:203-204

Bosch I, Martinez-Solano I, Garcia-Paris M (2001) Evidence of a chytrid fungus infection involved in the decline of the common midwife toad (Alytes obstetricans) in protected areas of central Spain. Biol Conserv 97:331-337

Boyle DG, Boyle DB, Olsen V, Morgan JAT, Hyatt AD (2004) Rapid quantitative detection of chytridiomycosis (Batrachochytrium dendrobatidis) in amphibian samples using realtime Taqman PCR assay. Dis Aquat Org 60:141-148

Bradley GA, Rosen PC, Sredl MJ, Jones TR, Longcore JE (2002) Chytridiomycosis in native Arizona frogs. J Wildl Dis 38:206

Carli A, Pane L, Casareto L, Bertone S, Pruzzo C (1993) Occurrence of Vibrio alginolyticus in Ligurian coast rock pools (Tyrrhenian Sea, Italy) and its association with the copepod Tigriopus fulvus (Fisher, 1860). Appl Environ Microbiol 59:1960-1962

Carlile MJ, Watkinson SC (1994) The fungi. Academic Press, London

Daszak P, Cunningham AA (1999) Extinction by infection. Trends Ecol Evol 14:279

Daszak P, Berger L, Cunningham AA, Hyatt AD, Green DE, Speare R (1999) Emerging infectious diseases and amphibian population declines. Emerg Infect Dis 5:735-748

Dewel RA, Joines JD, Bond JJ (1985) A new chytridiomycete parasitizing the tardigrade Milnesium tardigradum. Can J Bot 63:1525-1534

Dobson AP, May RM (1986) Disease and conservation. In: Soulé $M$ (ed) Conservation biology: the science of scarcity and diversity. Sinauer Associates, Sunderland, MA, p 345-365

Donnellan SC, Mahony MJ (2004) Allozyme, chromosmal and morphological variability in the Litoria lesueuri species group (Anura: Hylidae), including a description of a new species. Aust J Zool 52:1-28

Godfray HCJ, Briggs CJ, Barlow ND, O'Callaghan MO, Glare TR, Jackson TA (1999) A model of insect-pathogen dynamics in which a pathogenic bacterium can also reproduce saprophytically. Proc R Soc Lond B 266:233-240

Harris RN, James TY, Lauer A, Simon MA, Patel A (2006) Amphibian pathogen Batrachochytrium dendrobatidis is inhibited by the cutaneous bacteria of amphibian species. EcoHealth 3:53-56

Hood MA, Winter PA (1997) Attachment of Vibrio cholerae under various environmental conditions and to selected substrates. FEMS Microbiol Ecol 22:215-223
Johnson ML, Speare R (2003) Survival of Batrachochytrium dendrobatidis in water: quarantine and disease control implications. Emerg Infect Dis 9:922-925

Johnson ML, Speare R (2005) Possible modes of dissemination of the amphibian chytrid Batrachochytrium dendrobatidis in the environment. Dis Aquat Org 65:181-186

Kiesecker JM, Blaustein AR, Belden LK (2001) Complex causes of amphibian population declines. Nature 410:681-684

Langkilde T, Alford RA (2002) The tail wags the frog: harmonic radar transponders affect movement behavior in Litoria lesueuri. J Herpetol 36:711-715

Lips KR (1999) Mass mortality and population declines of anurans at an upland site in western Panama. Conserv Biol 13: $117-125$

Lips KR, Burrowes PA, Mendelson JR, Parra-Olea G (2005) Amphibian population declines in Latin America: a synthesis. Biotropica 37:222-226

Lips KR, Brem F, Brenes R, Reeve JD and 6 others (2006) Emerging infectious disease and the loss of biodiversity in a neotropical amphibian community. Proc Natl Acad Sci USA 103:3165-3170

Longcore JE (2005) Zoosporic fungi from Australian and New Zealand tree-canopy detritus. Aust J Ecol 53:259-272

Longcore JE, Pessier AP, Nichols DK (1999) Batrachochytrium dendrobatidis gen. et sp. nov., a chytrid pathogenic to amphibians. Mycologia 91:219-227

Muths E, Corn PS, Pessier AP, Green DE (2003) Evidence for disease-related amphibian decline in Colorado. Biol Conserv 110:357-365

Nichols DK, Lamirande EW, Pessier AP, Longcore JE (2001) Experimental transmission of cutaneous chytridiomycosis in dendrobatid frogs. J Wildl Dis 37:1-11

Parris KM, Cornelius TO (2004) Fungal pathogen causes competitive and developmental stress in larval amphibian communities. Ecology 85:3385-3395

Pessier AP, Nichols DK, Longcore JE, Fuller MS (1999) Cutaneous chytridiomycosis in poison dart frogs (Dendrobates spp.) and White's tree frogs (Litoria caerulea). J Vet Diagn Invest 11:194-199

Piotrowski JS, Annis SL, Longcore JE (2004) Physiology of Batrachochytrium dendrobatidis, a chytrid pathogen of amphibians. Mycologia 96:9-15

Powell MJ (1993) Looking at mycology with a Janus face: a glimpse of chytridiomycetes active in the environment. Mycologia 85:1-20

Rachowicz LJ, Vredenburg VT (2004) Transmission of Batrachochytrium dendrobatidis within and between amphibian life stages. Dis Aquat Org 61:71-82

Richards SJ, Sinsch U, Alford RA (1994) Radio tracking. In: Heyer WR, Donnelly MA, McDiarmid RW, Hayek LC, Foster MS (eds) Measuring and monitoring biological diversity: standard methods for amphibians. Smithsonian Institution Press, Washington, DC, p 155-157

Signoretto C, Burlacchini G, Pruzzo C, Canepari P (2005) Persistence of Enterococcus faecalis in aquatic environments via surface interactions with copepods. Appl Environ Microbiol 71:2756-2761

Sparrow FK (1960) Aquatic phycomycetes. University of Michigan Press, Ann Arbor, MI

Stuart SN, Chanson JS, Cox NA, Young BE, Rodrigues ASL, Fischman DL, Waller RW (2004) Status and trends of amphibian declines and extinctions worldwide. Science 306:1783-1786

Weldon C, Du Preez L (2004) Decline of the Kihansi spray toad, Nectophrynoides asperginis, from the Udzungwa Mountains, Tanzania. Froglog 62:2-3 